\title{
Milk Production and Sanitary Risk along the Food Chain in Five Cities in Burkina Faso
}

\author{
Hama Cissé, Adama Sawadogo, Boureima Kagambèga, Cheikna Zongo, Yves Traoré and \\ Aly Savadogo *
}

Laboratory of Applied Biochemistry and Immunology, University Ouaga, 1 Pr Joseph KI-ZERBO, 03 BP 7021 Ouagadougou 03, Burkina Faso; hama.cisse@univ-ouaga.bf (H.C.); adama.sawadogo@univ-ouaga.bf (A.S.); kagambou@gmail.com (B.K.); cheikna_zongo@univ-ouaga.bf (C.Z.); ytraore@yahoo.com (Y.T.)

* Correspondence: aly.savadogo@univ-ouaga.bf; Tel.: +226-703-562-27

Received: 24 June 2018; Accepted: 11 July 2018; Published: 13 July 2018

\begin{abstract}
Livestock is the third largest currency provider in Burkina Faso after gold and cotton. The objective of this study was to assess the socio-economic characteristics of actors, level of production and sanitary risks along the food chain of local fermented milk. A literature search and an investigation were conducted. Sphinx Plus ${ }^{2}-\mathrm{V} 5$ software was used for data processing and analysis. Results obtained show that milk processing is essentially a female activity and Fulani is the most active tribe in the milk sector. The curdling is done mainly using a curdled whey. Nutritional characteristics of fermented milk depend on the milk used, the milking conditions, the technology used, and a good curd must have a pleasant smell with a sweet and sour taste. The precariousness of milking, the lack of training in hygiene, the ignorance of the rules of hygiene, the state of environment of processing/sale, the strong use of antibiotics, the negligence of campaigns of vaccinations, and the non-compliance with the waiting period generate significant sanitary risks for consumers and animals. Livestock is the mainstay of the white revolution in Burkina Faso and contributes to food and socio-economic security.
\end{abstract}

Keywords: livestock; milk; processing; sanitary risk; Burkina Faso

\section{Introduction}

Milk is an important food for many populations in West Africa, mainly in Burkina Faso, where it forms the basis of diet in Sahel and Hauts-Bassins populations [1]. Milk is the main source of animal protein available in rural areas and highly consumed (in winter or throughout the year) especially during Ramadan. It is often added to certain foods at fresh state or curd (couscous, rice, galettes, tô, tchobal). It is a food of paramount importance in the nutrition of pregnant, lactating women, and infants. Although livestock farming has long been regarded as an activity reserved for the Fulani, its practice has today intensified and spread to all regions of the country because of the socio-economic and food benefits it offers [2,3].

Currently, the country's breeding is more focused on ruminants and poultry. Regarding the importance of livestock for the country's food security, the milk sector has been selected as a priority sector for revival of the livestock sector in the National Policy for Sustainable Development of Livestock with the horizon of 2025. This policy displays the guidelines for livestock development in Burkina Faso, and serves as a benchmark for medium- and long-term actions aimed at making Burkina Faso livestock farming "A competitive and environmentally friendly livestock farming around the world which organizes real value chains carried by professional sectors, turned the market and which contributes as much the food security as to improvement the level of well-being in Burkina Faso" [2]. 
The demand of animal products, especially milk, is growing steadily thanks to rising incomes, changing dietary patterns in recent years and lower prices compared to the period of the year. Therefore, if the actors of this sector obtained more training, equipment and worked to improve cattle breeds, milk production could reach 250 million liters per year [2]. The main products derived from its processing are curd, yogurt, wagashi, pasteurized milk, cream, butter and Katarè [4]. According to consumers, the quality of milk and dairy products varies enormously. Ignorance (or neglect) of hygiene rules during milk processing and the use of certain agricultural and veterinary inputs are often suspected as factors affecting this quality $[5,6]$.

The processing and marketing of dairy products is an income-generating activity practiced in both urban and rural areas and has intensified in Burkina Faso and in the West Africa sub-region. It would be interesting to evaluate the sanitary risks associated with the production and sale of local milk to inform processors about the corrective measures to be applied for reducing food poisoning without compromising the availability of food, dairy farmers' income, and economic development. The methods used to carry out this study are the literature search and the use of a participatory risk analysis process associated with the practices of actors and risks to the contamination of dairy products along the food chain. The research questions and the resulting hypotheses make it possible to define the objectives of this work. The exploitation of different practices of actors in the milk sector can make it possible to meet the requirements for the safety of milk and dairy products in Burkina Faso, which leads to the following questions: what are the risky practices of actors from the production to sale of milk? What are the consumer's opinions on the sanitary quality of milk and dairy products consumed in Burkina Faso?

This study, therefore, aims to assess the socio-economic characteristics of actors, the level of consumption, the consumers' opinion on the quality of local curd and sanitary risk factors associated with it along the food chain.

\section{Results}

\subsection{Overview Livestock in Burkina Faso}

Burkina Faso has one of the largest cattle herds in West Africa behind Mali, with more than 9 million heads in 2014. In Burkina Faso, livestock occupy $30 \%$ of labor force, $80 \%$ of households and contributes almost $20 \%$ of total GDP (gross national product) and $14.2 \%$ of total exports of country. It thus constitutes the third currency provider of the country after gold and cotton [2,3]. Livestock is a secondary economic activity for some people; it is also a first recourse of poor populations to obtain the incomes necessary for purchasing cereals in provision to the difficult periods, convergent with the improvement of food safety, diversification and increase the incomes of actors [7]. Milk is used in food under various forms according to locations and food practices of sociocultural groups [8]. Thus, its promotion would be interesting and necessary to ensure the food safety and economic growth in the country, hence, the question of Oudet [9] is "the white revolution (milk sector) of India of the Seventies years would be it possible in Burkina Faso in which conditions?"

\subsection{Sociocultural Characteristics of Breeder, Producer-Salesmen and Consumers of Milk}

Table 1 shows the sociocultural characteristics of a population survey. This total population consists of $60.42 \%$ women and $39.58 \%$ men. It was shown from investigations that the practice of livestock is an activity undertaken by men $(58.75 \%)$ and women $(41.25 \%)$ with no significant difference $\left(\mathrm{Chi}^{2}=2.45 ; p=0.11\right)$. The processing-sale of milk is mainly practiced by women $(78.75 \%)$, but is also carried out by men $(21.25 \%)$. In terms of consumption, there is no significant difference but this is slightly dominated by women $61.25 \%\left(\mathrm{Chi}^{2}=2.45 ; p=0.12\right)$. This population is divided into four groups for age; the first group, of less than 18 years old, accounts $1.66 \%$ of respondents; the second from 18 to 24 years $20.42 \%$; the third from 24 to 28 years $15 \%$; and the last group of more than 28 years old is $62.92 \%$ of respondents. The difference in distribution of age is very significant $\left(\mathrm{Chi}^{2}=61.22\right.$; 
$p<0.0001)$. This population includes 11 socio-ethnic groups, mainly, Fulani (35.83\%), Bella $(12.08 \%)$ and Mossi (10.42\%). Most actors in the milk sector are Fulani with $43.75 \%$ of breeders/producers, $35 \%$ of transformer-saleswomen and $28.75 \%$ of consumers. Concerning the educational level of respondents, the majority is illiterate $(29.58 \%), 12.50 \%$ koranic, $19.17 \%$ received an instruction in local language, $9.58 \%$ college level, $4.58 \%$ secondary level, $2.50 \%$ university level, and $22.09 \%$ primary studies.

Table 1. Sociocultural characteristics of respondent.

\begin{tabular}{|c|c|c|c|c|c|c|c|c|c|}
\hline \multirow{2}{*}{\multicolumn{2}{|c|}{ Variable }} & \multicolumn{2}{|c|}{ Breeder } & \multicolumn{2}{|c|}{ Transformer-Seller } & \multicolumn{2}{|c|}{ Consumers } & \multicolumn{2}{|c|}{ Total } \\
\hline & & $\mathbf{N}(80)$ & F (\%) & $\mathbf{N}(80)$ & F (\%) & N (80) & F (\%) & N (240) & F (\%) \\
\hline \multirow{2}{*}{ Sex } & Female & 33 & 41.25 & 63 & 78.75 & 49 & 61.25 & 145 & 60.42 \\
\hline & Male & 47 & 58.75 & 17 & 21.25 & 31 & 38.75 & 95 & 39.58 \\
\hline \multirow{4}{*}{ Ages } & $\leq 18$ & - & - & 1 & 1.25 & 3 & 3.75 & 4 & 1.66 \\
\hline & $18-24$ & 7 & 8.75 & 13 & 16.25 & 29 & 36.25 & 49 & 20.42 \\
\hline & $24-28$ & 11 & 13.75 & 12 & 15 & 13 & 16.25 & 36 & 15 \\
\hline & $\geq 28$ & 62 & 77.50 & 54 & 67.50 & 35 & 43.75 & 151 & 62.92 \\
\hline \multirow{7}{*}{ Instruction } & Illiterate & 28 & 35 & 24 & 30 & 19 & 23.75 & 71 & 29.58 \\
\hline & Koranic & 13 & 16.25 & 8 & 10 & 9 & 11.25 & 30 & 12.50 \\
\hline & Local & 15 & 18.75 & 19 & 23.75 & 12 & 15 & 46 & 19.17 \\
\hline & Primary & 18 & 22.50 & 15 & 18.75 & 20 & 25 & 53 & 22.09 \\
\hline & College & 6 & 7.50 & 9 & 11.25 & 8 & 10 & 23 & 9.58 \\
\hline & Secondary & - & - & 3 & 3.75 & 8 & 10 & 11 & 4.58 \\
\hline & University & - & - & 2 & 2.50 & 4 & 5 & 6 & 2.50 \\
\hline \multirow{11}{*}{$\begin{array}{l}\text { Ethnos } \\
\text { Group }\end{array}$} & Bella & 9 & 11.25 & 13 & 16.25 & 7 & 8.75 & 29 & 12.08 \\
\hline & Bissa & - & - & 2 & 2.50 & 4 & 5 & 6 & 2.50 \\
\hline & Bobo/Dioula & 4 & 5 & 4 & 5 & 6 & 7.50 & 14 & 5.83 \\
\hline & Foulché & 7 & 8.75 & 9 & 11.25 & 7 & 8.75 & 23 & 9.58 \\
\hline & Gourmantché & 6 & 7.50 & 5 & 6.25 & 4 & 5 & 15 & 6.25 \\
\hline & Gourounsi & - & - & 2 & 2.50 & 3 & 3.75 & 5 & 2.08 \\
\hline & Haoussa & 7 & 8.75 & 10 & 12.50 & 5 & 6.25 & 22 & 9.17 \\
\hline & Mossi & 7 & 8.75 & 7 & 8.75 & 11 & 13.75 & 25 & 10.42 \\
\hline & Fulani & 35 & 43.75 & 28 & 35 & 23 & 28.75 & 86 & 35.83 \\
\hline & Sam & - & - & - & - & 2 & 2.50 & 2 & 0.83 \\
\hline & Touareg & 5 & 6.25 & - & - & 8 & 10 & 13 & 5.43 \\
\hline
\end{tabular}

$\mathrm{N}$ : Number, F: Frequency.

\subsection{Practices of Livestock}

\subsubsection{Livestock, Processing of Milk and Distribution Chain of Milk and Dairy Products}

Table 2 reveals that the traditional livestock (83.75\%) is the most important in Burkina Faso with significant difference $\left(\mathrm{Chi}^{2}=36.45, p<0.001\right)$ with other forms of livestock. The domestic animals used for milk transforming are camels (11.45\%), cows (39.76\%), ewes (23.49\%) and goats $(25.30 \%)$. On the whole, $60 \%$ of breeders have 2 to 6 dairy females and $35 \%$ have a production of milk reaching 4 to $8 \mathrm{~L}$ per day.

The milking is done manually $100 \%$ (Figure 1A,B) and the provender used to nourish animals is composed of bran, oil cakes and remainders of meal. The processing of milk is mainly done in a familial way $78.75 \%$ with a restricted workforce from 1 to 3 people (38.75\%) transforming a quantity of milk varying between 6 to $14 \mathrm{~L}$ per day. Commonly processed milks are cow milk $(43.24 \%)$, goat milk $(21.62 \%)$, milk powder $(19.59 \%)$, camel milk $(15.54 \%)$ with significant difference $\left(\mathrm{Chi}^{2}=158.96, p\right.$ $<0.00001)$. Most transformers-sellers (55.88\%) are supplied by local suppliers and 55\% of these transformers use the curd of eve as a fermentation inoculum. Figure 1C shows a spice used to improve the organoleptic qualities of curdled milk (spicy curd). Processing utensils are calabashes, gourds (traditional or goat leather Figure 1D) and dishes (iron, aluminum, plastic). Milk processing 
offers a wide range of products: fermented milk, pasteurized milk, yogurt, stirred yogurts (Moringa, Pineapple and Lemon), cream, butter, and buttermilk, cheese, and Fulani soap. The marketing of these products is an income-generating activity and $95 \%$ of respondents confirm the profitability of this activity. The milk sold is intended for consumption $(53.06 \%)$, resale $(30.61 \%)$, traditional practices $(16.30 \%)$ and these practices are significantly different $\left(\mathrm{Chi}^{2}=88.07, p<0.0001\right)$. These traditional practices are baptism, marriage, and sacrifice.

Table 2. Livestocking and milk production for fermentation.

\begin{tabular}{|c|c|}
\hline Variables & Modalities and Frequency \\
\hline \multicolumn{2}{|r|}{ Livestock and Milking } \\
\hline Type of Livestock & Modern $(16.25 \%)$, Traditional $(83.75 \%)$ \\
\hline Animals for Milk Production & Sheep (23.49\%), Camel (11.45\%), Goat (25.30\%), Cow (39.76\%) \\
\hline Number of Female & $1-2(2.50 \%), 2-6(60 \%), 6-12(27.50 \%), 12-20(10 \%)$ \\
\hline Type of Milking & Manual (100\%), Mechanical (00\%) \\
\hline Quantity Produced per Day & $1-4(8.75 \%), 4-8(35 \%), 8-12(26.25 \%), 12-20(30 \%)$ \\
\hline Livestock Feed & Cakes, Animal Meal, Herbs, Cereals (Stems and Bran), Leftovers \\
\hline \multicolumn{2}{|r|}{ Milk Processing } \\
\hline Type of Production & Artisanal (31.25\%), Family (53.75\%), Semi-industrial (15\%), Industrial (0\%) \\
\hline Number of Employees & $1-3(78.75 \%), 3-6(17.50 \%), 6-9(2.50 \%), 9-15(1.25 \%)$ \\
\hline Type of Milk used & Camel (15.54\%), Goat (21.62\%), Powdered Milk (19.59\%), Cow $(43.24 \%)$ \\
\hline Quantity of processed milk & $1-6(32.50 \%), 6-14(38.75 \%), 14-50(28.75 \%)$ \\
\hline Milk Supply & Collection (23.53\%), Suppliers (55.88\%), Self (20.59\%) \\
\hline Fermentation Technology & Industrial Lactic Ferments (31.25\%), Whey Curd (55\%), Spontaneous $(13.75 \%)$ \\
\hline Material of Fermentation & Calabash, Gourd, Dishes \\
\hline Products obtained after Fermentation & $\begin{array}{c}\text { Curd, Pasteurized Milk, Yogurt, Stirred Yogurt (Moringa, Pineapple, Lemon), } \\
\text { Butter, Butterbur, Cream, Cheese and Soap Fulani }\end{array}$ \\
\hline Profitability of the Activity & Yes $(95 \%)$, No $(5 \%)$ \\
\hline Becoming Milk after the Sale & Consumption (53.06\%), Traditional Practices (16.33\%), Resale (30.61\%) \\
\hline
\end{tabular}

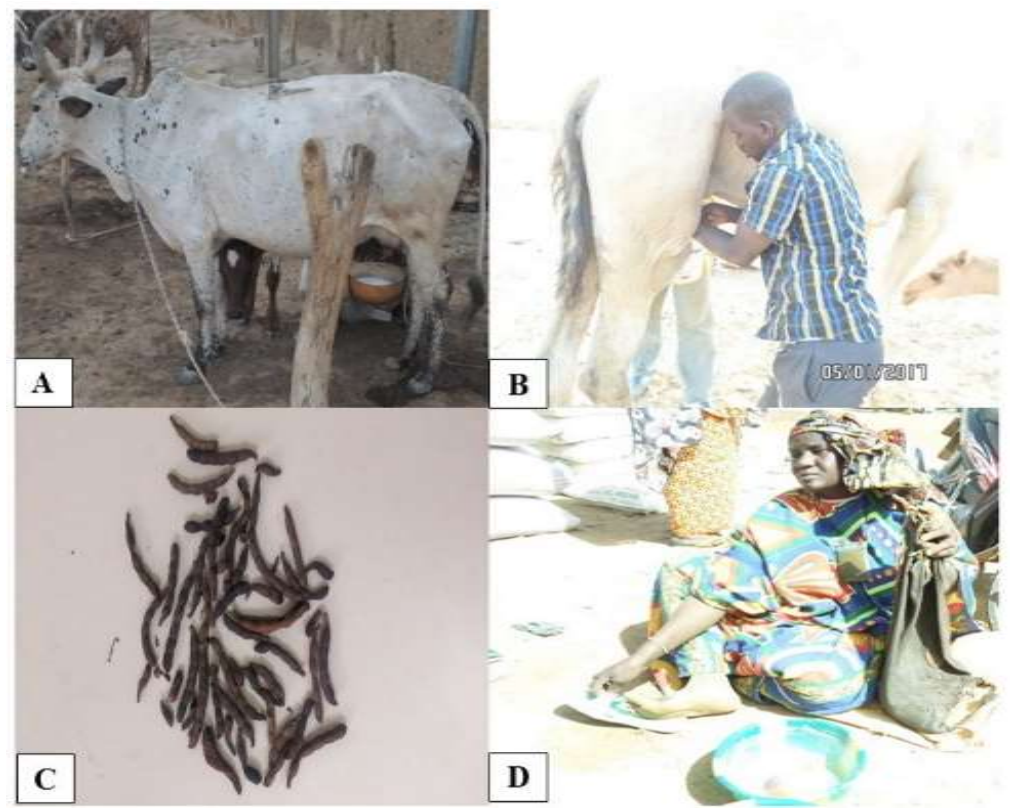

Figure 1. Milking Cow (A), Camel (B), Spice (C) and Leather Gourd containing Milk (D).

From milking and to processing, milk knows important trading patterns (Figure 2). The direct circuit from producer to consumer or traditional collectors-suppliers to processors or consumers (1) and the modern circuit (2) are the most practiced and depend on a processing unit. A new fraud 
circuit has developed (3) in urban centers and poses a threat to local producers. The importance of the circuit depends on the quantity of milk exchanged and the actors involved.

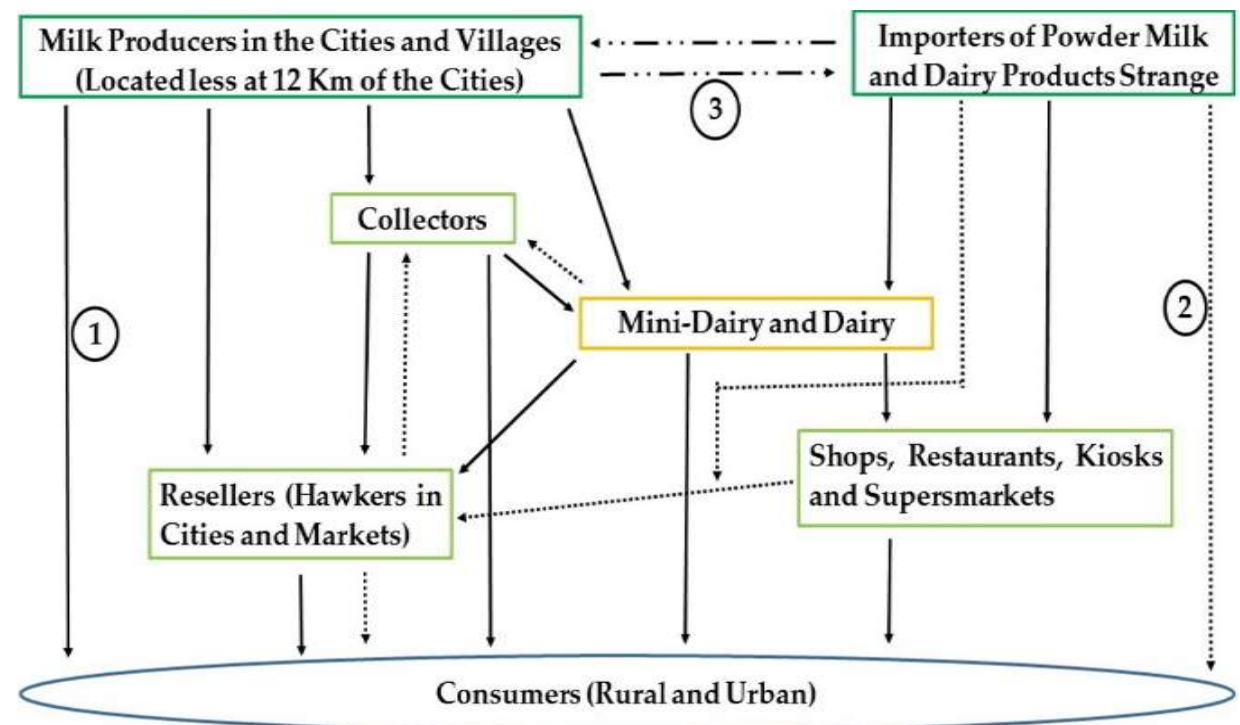

Legend. Direct Circuit (1), Modern Circuit (2) and Fraud Circuit (3).

Figure 2. Milk and dairy products marketing circuit of the cities in Burkina Faso.

\subsubsection{Consumer Assessment of Conditions Production and Sale at Local Milk}

Milk is a popular food for local populations. 100\% of respondents believe they consume milk frequently with significant difference for the consumption frequencies $\left(\mathrm{Chi}^{2}=50.90, p<0.0001\right)$, weekly $(53.75 \%)$, daily $(31.25 \%)$ and monthly $(15 \%)$. Cow milk $(47.50 \%)$ is the most commonly consumed, followed by goat milk $(21.25 \%)$, camel milk $(17.50 \%)$, milk powder $(11.25 \%)$ and soy milk "vegetable milk" (2.50\%). The most consumed forms of milk are fresh milk $(43.55 \%)$, curd/yogurt (39.88\%), brewed milk (8.59\%) and pasteurized milk (7.98\%) with a highly significant difference $\left(\mathrm{Chi}^{2}=73.34, p<0.0001\right)$. Type and shape of milk consumed depends on the consumer's choice. Reasons given are multiple (Table 3). Only $73.75 \%$ know the origin of the milk they consume, and the places of supply are mainly the farms/home of producer $(46.19 \%)$ and markets/streets $(25.15 \%)$. Local curd is highly appreciated by consumers $(93.75 \%)$ and curd taste varies from one consumer to another (42.74\% sour; $30.78 \%$ bitter-sweet; $19.65 \%$ salted and $6.83 \%$ sweet). $31.25 \%$ of consumers doubt the quality of milk sold and $62.50 \%$ say that local milk meets their expectations.

Table 3. Consumption and assessment of the local curd.

\begin{tabular}{|c|c|}
\hline Variables & Modalities and Frequency \\
\hline Consumption of Milk & $\begin{array}{c}\text { Yes (100\%), No (00\%) } \\
\text { Daily (31.25\%), Weekly (53.75\%), Monthly }(15 \%)\end{array}$ \\
\hline Type of Milk consumed & Camel $(17.50 \%)$, Goat $(21.25 \%)$, Cow $(47.50 \%)$, Milk Powder $(11.25 \%)$, Soy Milk $(2.50 \%)$ \\
\hline Form of Milk consumed & Brewed (8.59\%), Curd/Yogurt (39.88\%), Fresh (43.55\%), Pasteurized $(7.98 \%)$ \\
\hline Reason of Choice & Available, Less Expensive, Therapeutic, Beneficial, Pleasant Oder \\
\hline Knowledge of the Origin of Milk & Yes $(73.75 \%)$, No $(26.25 \%)$ \\
\hline Places of Supply & $\begin{array}{c}\text { Shops (15.79\%), Farms / Home of Producer }(46.19 \%) \text {, Dairies }(7.02 \%) \text {, } \\
\text { Markets/Streets }(25.15 \%) \text {, Restaurants }(5.85 \%)\end{array}$ \\
\hline Do you like Local Curd & Yes $(93.75 \%)$, No $(6.25 \%)$ \\
\hline Taste of the Curd Consumed & Sour $(42.74 \%)$, Bitter-Sweet $(30.78 \%)$, Salted $(19.65 \%)$, Sweet $(6.83 \%)$ \\
\hline Do you doubt the Quality this Milk? & Yes $(31.25 \%)$, No $(68.78 \%)$ \\
\hline Does milk meet your expectation? & Yes $(62.50 \%)$, No $(37.50 \%)$ \\
\hline
\end{tabular}




\subsubsection{Uses of Antibiotics and Animal Vaccination Program}

Figure 3 shows a high use of antibiotics (ATBs) by $91.30 \%$ of breeder and low participation in vaccination campaigns $(28.75 \%)$. The products used are vaccines, antiparasitics, vitamins, anti-inflammatories, and ATBs. The results of the investigation showed that $55.22 \%$ of these ATBs generally used to cure animals are recommended mainly by veterinarians $(43.75 \%)$ and street traders $(18.75 \%)$ on market days. A large proportion of breeders (70\%) observe waiting times of 6 days $58.73 \%$ $\left(\mathrm{Chi}^{2}=23, p<0.001\right)$ and others at more than 12 days $(14.29 \%)$ prior to milking of vaccinated animals or those receiving ATBs. ATBs prescribed by veterinarians are Penicillin G, Tetracycline, Sulfamide, Ampicillin, Colistin, Erythromycin, Furaltadone, Ivermectin, Megacilin, Neomycin, Norfloxacin, Oxytetracycline, Peni-streptomycin, Tylosin, and Tenaline. However, the most ATBs known by respondents are Daffonor, Ivermectin, Penicillins, Tetracyclines, and Sulfonamides.

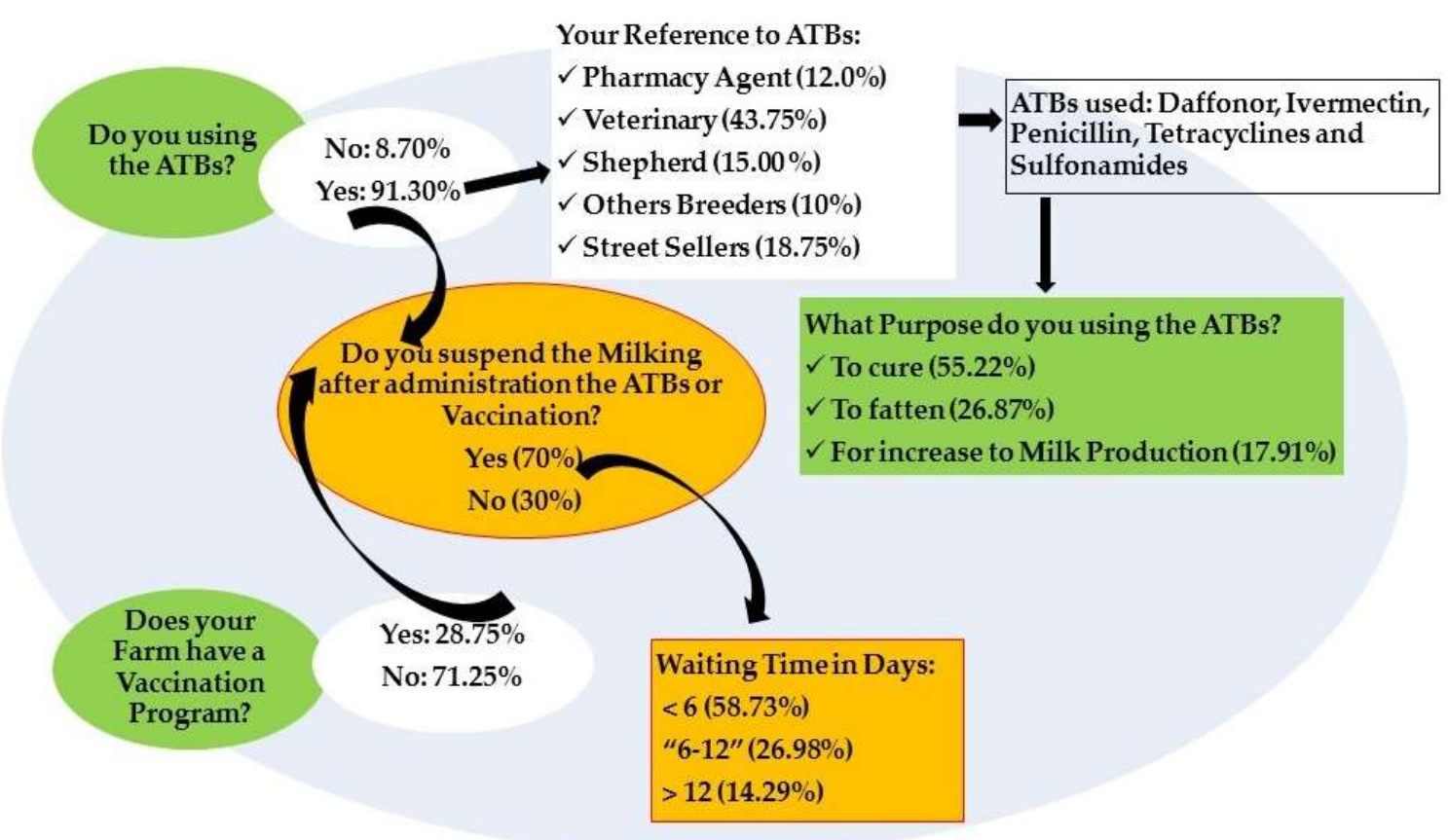

Figure 3. Synthesis on the use of antibiotics and vaccination of animals.

\subsection{Sanitary Risks Along the Food Chain}

\subsubsection{Sanitary Risks at Dairy Breeders}

In dairy breeders, sanitary risks are encountered at three levels: feeding, animal health, and milking conditions (Table 4). At the feed level, management of animal sludge, food storage, water quality and watering equipment are very important parameters. $66.25 \%$ of breeders have no sludge management system, $18.75 \%$ use manure pits and $15 \%$ store directly in pen with the animals. As for food, only $34.56 \%$ of breeders have equipped and covered areas intended only to store animal feed. The others store feed in an open area covered (29.41\%) and uncovered (36.03\%). Drinking water comes from four different sources: pools $(32.67 \%)$, boreholes $(20.60 \%)$, wells $(28.64 \%)$ and faucet $(18.09 \%)$. The nature of watering place differs according to standard of living and type of breeding practiced $(52.74 \%)$. In urban cities, cement bins $(4.97 \%)$ and metal or plastic dishes are widely used. 
Table 4. Standard sanitary risk at dairy breeders.

\begin{tabular}{|c|c|c|}
\hline Level & Variables & Modalities and Frequency \\
\hline \multirow{5}{*}{ Animal Feed } & System Management of the Mud & None (66.25\%), Manure Pit (18.75\%), Enclosure (15\%) \\
\hline & Feed Storage System & Free covered Area (29.41\%), Uncovered Free Area (36.03\%), Space arranged and covered $(34.56 \%)$ \\
\hline & Origin of Drinking Water & Faucet $(18.09 \%)$, Well (28.64\%), Drilling (20.60\%), Pond/Backwater (32.67\%) \\
\hline & Nature of the Feeding Trough & Wood (12.44\%), Cement (4.97\%), Hollow (6.47\%), Reserve (23.38\%), Metal/Plastic Dishes (52.74\%) \\
\hline & Contamination of Water and Provender by & Human and Animal Excreta (48.86\%), Mining Activities (18.56\%), Toxic Substances (32.58\%) \\
\hline \multirow{4}{*}{ State Sanitary of Animals } & Bovines Mastitis & Yes $(48.75 \%)$, No $(51.25 \%)$ \\
\hline & Staff contacted in the Event of Diseases & Others (31.25\%), Shepherd (38.75\%), Veterinary $(30 \%)$ \\
\hline & Diseases and Damages recorded & Abortion (2.89\%), Premature Calving (4.81\%), Newborns deformities (2.40\%), Diarrhea (33.17\%), \\
\hline & Animals deformed Further to Diseases & $\begin{array}{c}\text { Deaths (20.67\%), Respiratory Diseases }(22.60 \%), \text { Scabies }(13.46 \%) \\
\text { None }(77.50 \%), 1-2(15 \%), 2-4(7.50 \%)\end{array}$ \\
\hline \multirow{8}{*}{ Conditions of Milking } & Place of Milking & Enclosure (26.25\%), Space arranged (13.75\%), Pasture (18.75\%), Attachment Point $(41.25 \%)$ \\
\hline & Cleaning the Material of the Milking & Before and After $(57.50 \%)$, Before $(3.75 \%)$, Before $(38.75 \%)$ \\
\hline & The Dress of the Milker & Clean $(18.75 \%)$, Acceptable $(56.25 \%)$, Sale $(25 \%)$ \\
\hline & Washing the Hand of the Milker & $\begin{array}{l}\text { Before Milking }(8.75 \%) \text {, After Milking (35\%), Before and After Milking (20\%), Simple Rubbing the Hands or } \\
\text { Clothing by Milkers (5\%), Do not pay attention (31.25\%) }\end{array}$ \\
\hline & Cleaning of Teat before the Milking & Simple Water $(7.50 \%)$, Material $(2.50 \%)$, Hands of the Milker $(17.50 \%)$, Teat abandoned to Calf $(72.50 \%)$ \\
\hline & Rejection of the First Gush & Yes $(13.75 \%)$, No $(86.25 \%)$ \\
\hline & Cleaning of Teat after the Milking & Simple Water (5\%), Material (2.50\%), Teat abandoned to Calf $(92.50 \%)$ \\
\hline & Treatment of Milk & None (13.75\%), Decanting (6.25\%), Decanting and Filtration (35\%), Filtration $(31.25 \%)$, Heating $(13.75 \%)$ \\
\hline
\end{tabular}


In rural areas, breeders practicing transhumance use wooden water troughs $(12.44 \%)$, hollows $(6.47 \%)$ and direct watering in water reserve $(23.38 \%)$. Whatever the origin of water and nature of drinking trough, drinking water is subject to contamination by human and animal excreta $(48.86 \%)$, mining activities (18.56\%) and agricultural, hospital and engine toxic substances (32.58\%). In rural cities and urban outskirts, there is a lack of sanitation systems by some households leading to open defecation (Figure 4A), exposure of feed to contaminations by human excreta due to poor waste water management (Figure 4B), waste (Figure 4C), and toxic products from mining activity during water abstraction by contaminated material (Figure 4D). In terms of animal health status, bovine mastitis is common $48.75 \%\left(\mathrm{Chi}^{2}=0.05, p=0.82\right)$ and animal health professionals are less consulted $30 \%$ $\left(\mathrm{Chi}^{2}=1.08, p=0.58\right)$ in case of diseases in favor of herders $(38.75 \%)$ and other people such as street traders of veterinary products and breeder friends (31.25\%). The diseases and damages recorded are respiratory diseases $(22.60 \%)$, scabies $(13.46 \%)$, diarrhea $(33.17 \%)$, abortions $(2.89 \%)$, premature calving $(4.81 \%)$, newborns deformities $(2.40 \%$, Figure $4 \mathrm{E})$ and deaths $(20.67 \%)$ with highly significant difference $\left(\mathrm{Chi}^{2}=120.60, p<0.0001\right)$. Figure $4 \mathrm{~F}$ shows the calves themselves thirst-quenching in a backwater at drying up. Because of these diseases, some animals are deformed; $15 \%$ and $7.50 \%$ of breeders respectively counted a number between 1 to 2 and 2 to 4 animals deformed with a highly significant difference $\left(\mathrm{Chi}^{2}=166.38, p<0.0001\right)$. Finally, milking conditions are important parameters on the sanitary quality of milk. At the end of investigation, milking is carried out mainly at the animal's attachment point at $41.25 \%$. Milking equipment is washed before and after milking according to $57.50 \%$ of the respondents; the milker's outfit is found to be clean only by $18.75 \%$, acceptable by $56.25 \%$ and dirty by $25 \%$. Regarding the milker's hand-washing, $8.75 \%$ confirm that this hygienic gesture is carried out before milking, 35\% estimate it after milking, 20\% before and after milking, $5 \%$ notice a simple rubbing the hands or clothing by milkers and $31.25 \%$ do not pay attention.

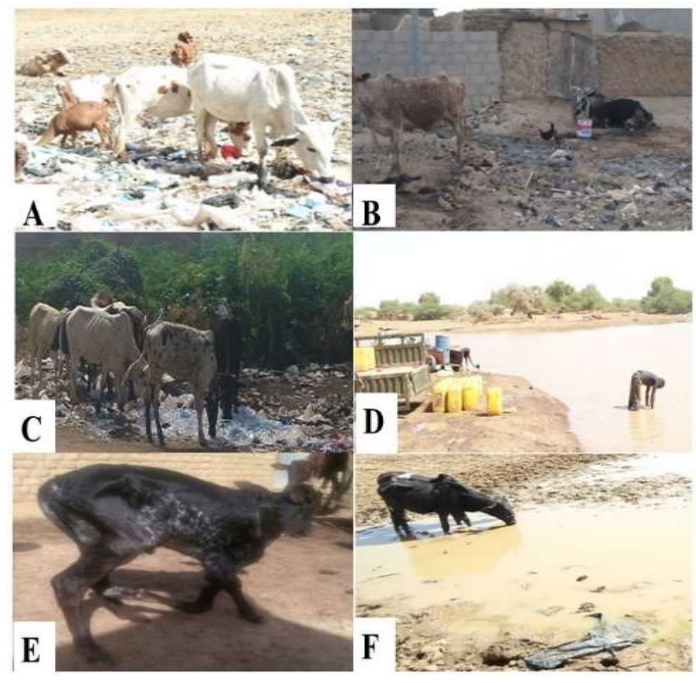

Figure 4. Exposure of Animals to the Human Excreta (A,B), Plastic Waste (C), Taking Water by the Mining in Activities (D), Newborn deformities (E) and Drinking in Mare (F).

\subsubsection{Sanitary Risks of Milk Processing-Sale}

The state of processing and marketing environment are one of the risks leading to possible contamination of milk by pathogens from other animals, manipulators, and environment (Table 5). The processing is done either in a free area $(13.75 \%)$, houses $(45 \%)$ or under sheds $(41.25 \%)$. Places of sale $(22.50 \%)$ are dirtier than places of processing $(18.75 \%)$. The presence of dust $(58.75 \%)$, puddles (15\%) and animals (stray animals, birds, insects with $68.75 \%$ ) are found on equipment used, places of processing, and sales. In terms of hygiene, only $22.50 \%$ of actors have received training, $6.25 \%$ declare having a quality controller and $2.50 \%$ have a quality monitoring manual. $17.50 \%$ of 
producer-sellers confirm using a special dress for their activity, whose condition is often dirty $23.75 \%$. Equipment is cleaned frequently before and after processing $(66.25 \%)$ with soap $(80.90 \%)$, and $50 \%$ of actors use water from the distribution faucet for cleaning. $48.75 \%$ of actors use well-preserved and debris-free water considered clean. The heating/filtration operation of milk before processing is carried out by $48.75 \%$ of the producers and makes it possible to obtain milk without debris (without hair of animals or producers, sand, aerosols, and parasites) and is, therefore, visibly clean (51.25\%).

Table 5. Sanitary risks from processing to sale of milk.

\begin{tabular}{|c|c|c|}
\hline State & Variables & Modalities and Frequency \\
\hline \multirow{3}{*}{$\begin{array}{l}\text { Processing and Sales } \\
\text { Environment }\end{array}$} & Place of Processing & $\begin{array}{l}\text { Free Area }(13.75 \%), \text { House }(45 \%) \text {, Shed }(41.25 \%) \\
\text { Clean }(31.25 \%) \text {, Acceptable }(50 \%) \text {, Dirty }(18.75 \%)\end{array}$ \\
\hline & Presence of & $\begin{array}{c}\text { Dust: Yes (58.75\%), No }(41.25 \%) \\
\text { Puddles: Yes (15\%), No (85\%) } \\
\text { Stray Animals, Insects and Poultry: Yes }(68.75 \%), \text { No }(31.25 \%)\end{array}$ \\
\hline & State the Point of Sale & Clean (32.50\%), Acceptable (45\%), Dirty (22.50\%) \\
\hline Hygiene & $\begin{array}{l}\text { Hygiene Training } \\
\text { Quality Controller } \\
\text { Monitoring Manual } \\
\text { Special Dress to Activity } \\
\text { State of the Dress } \\
\text { Cleaning of the Material } \\
\text { Disinfectant used } \\
\text { Origin of Water } \\
\text { Quality at Sight of Eye }\end{array}$ & $\begin{array}{c}\text { Yes }(22.50 \%), \text { No }(77.50 \%) \\
\text { Yes }(6.25 \%), \text { No }(93.75 \%) \\
\text { Yes }(2.50 \%) \text {, No }(97.50 \%) \\
\text { Yes }(17.50 \%) \text {, No }(82.50 \%) \\
\text { Clean (26.25\%), Acceptable }(50 \%), \text { Dirty }(23.75 \%) \\
\text { Before and After }(66.25 \%) \text {, Before }(8.75 \%) \text {, After }(25 \%) \\
\text { Bleach (14.55\%), Hot Water }(4.55 \%) \text {, Soaps }(80.90 \%) \\
\text { Faucet }(50 \%) \text {, Boring }(26.25 \%), \text { Well }(23.75 \%) \\
\text { Clean }(48.75 \%) \text {, Acceptable }(41.25 \%) \text {, Dirty }(10 \%)\end{array}$ \\
\hline \multicolumn{2}{|c|}{ Unitary Operation before Transformation } & $\begin{array}{c}\text { Heating (10\%), Decanting (20\%), Filtration (21.25\%), } \\
\text { Heating/Filtration ( } 48.75 \%)\end{array}$ \\
\hline \multicolumn{2}{|c|}{ Opinion of Customers on Quality at Sight of Eye } & Clean (51.25\%), Acceptable (40\%), Dirty $(8.75 \%)$ \\
\hline
\end{tabular}

\subsubsection{Sanitary Risk Analysis at Consumer}

The practices of some consumers create risks of contamination in the milk before consumption (Figure 5). $61.25 \%$ of respondents kept the purchased milk before consuming it. This conservation is usually done in canaris, at room or shed temperature often, causing an alteration or an invisible beginning of alteration $(66.25 \%)$ of milk before consumption; this predisposes the consumer to diseases $(55 \%)$ and questioning the application of hygienic rules by producers-sellers $(46.25 \%)$.

Do you think that Producers are applying Hygienic Rules correctly?

Have you gone to consult in Health Service?

Have you been Sick after to consumption the Local Milk?

Have you encountered any Alterations in the preserved Milk?

Do you keep the Milk before Consumption?

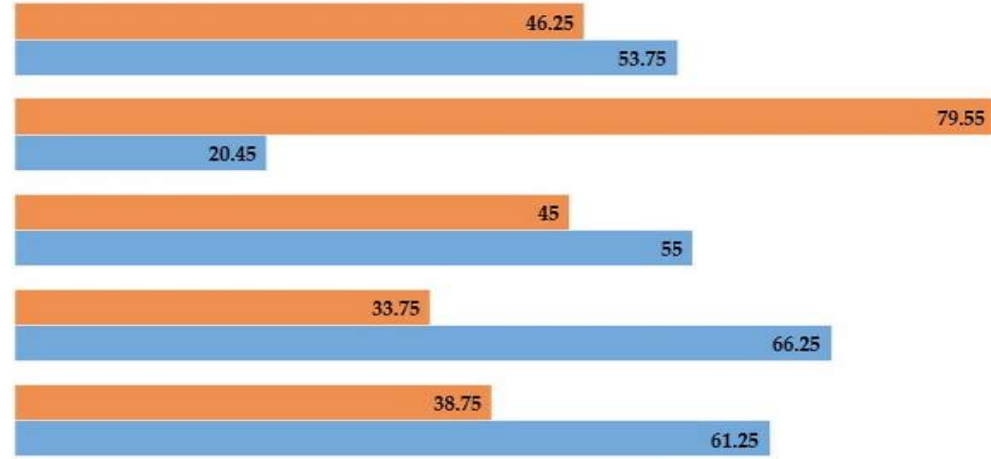

Figure 5. Practices of Consumer's.

In the case of visible damage (Figure 6A), this milk is mixed with animal feed (53\%) or poured into bins (45\%) and often processed for consumption (2\%). Clinical signs are shown in Figure 6B with a highly significant difference $\left(\mathrm{Chi}^{2}=69.70, p<0.0001\right)$; only $20.45 \%$ of people who manifested these signs went to a health center. 

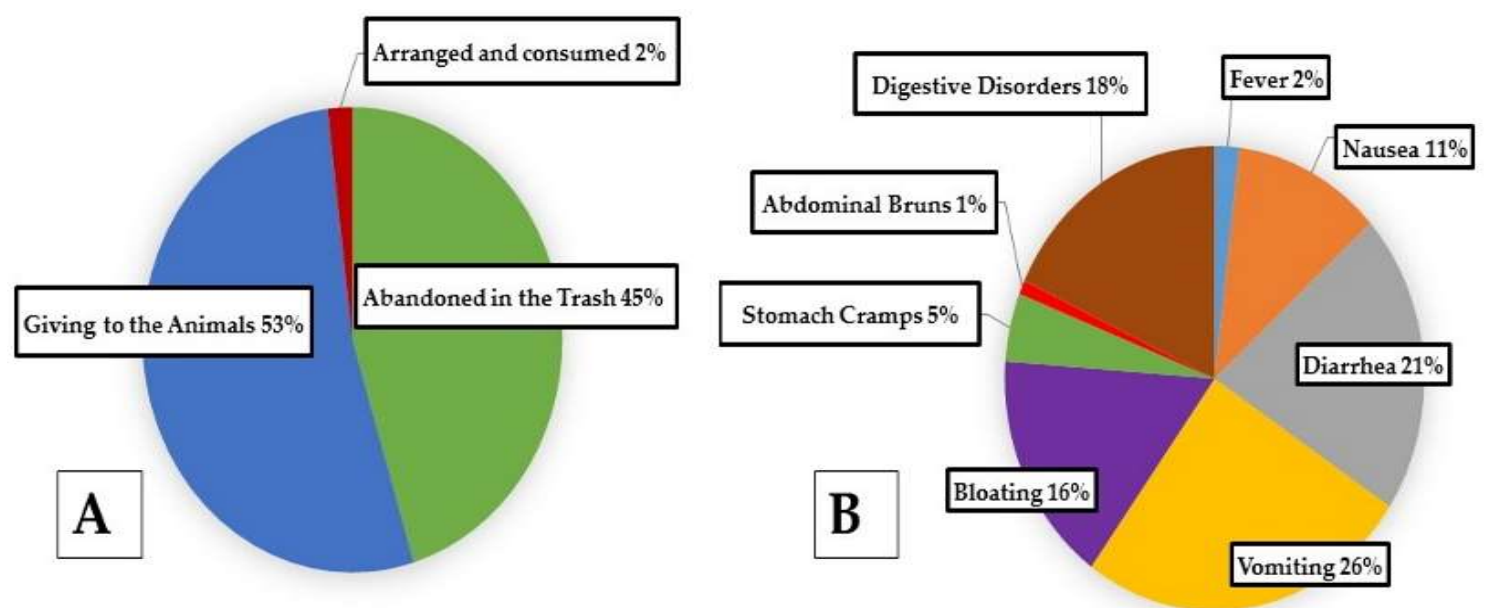

Figure 6. Management of altered Milk (A) and Clinical Signs (B).

Figure 7 shows that the perception of state of the sales environment and opinion on milk quality differ from one place to another and from one consumer to another. $51.25 \%$ of consumers say that hygienic quality is one of the main factors limiting their consumption of local curd.

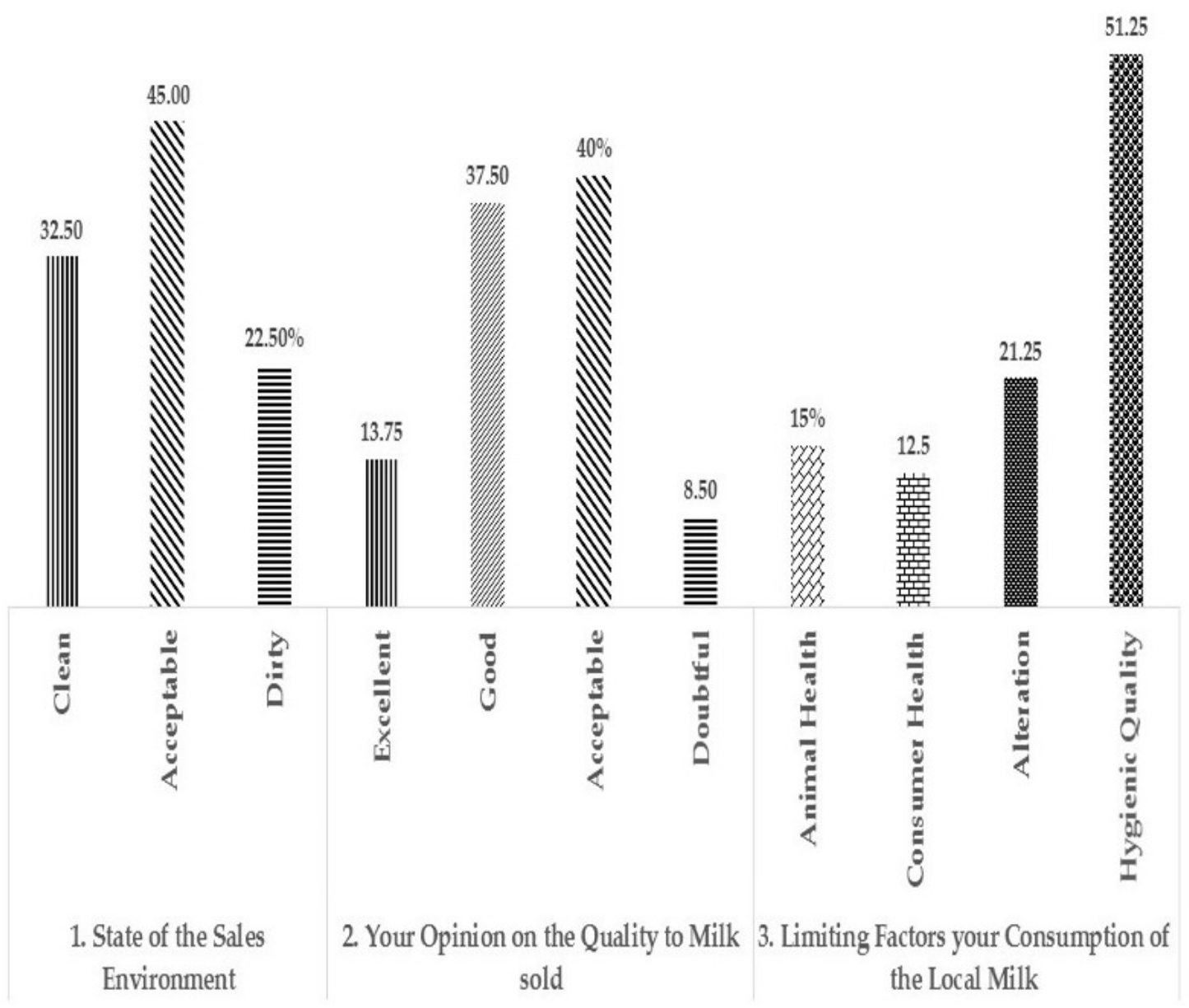

Figure 7. Sales environment (1), Opinion of consumers (2) and Limiting factors to consumption local milk's (3). 


\section{Discussion}

Livestock is a wealth and a biodiversity to be valued. Four regions include the majority of Burkina Faso's herds: Sahel, Hauts-Bassins, Boucle du Mouhoun and Centre Ouest. Milk production is highly regionalized and Sahel region is the country's dairy basin [1]. Milk is an essential source of food security and family income for many nomadic and sedentary populations in sub-Saharan Africa [10]. Its combination with cereals allows people to fight malnutrition due to nutrient deficiency in diets.

The study of sociocultural characteristics of actors showed that activities of breeding and milk production are essentially done by men (Table 1). These activities occupy men and women of different age groups with a low level of education, dominated by Fulani and Bella. Processing and marketing are generally provided by women with a low level of education. Women owners of livestock are less mobile than men because of their household tasks. This situation limits their possession and management to small livestock sheep, goats, and poultry. Women are large consumers of dairy products are associated with cereal [11]. Animal and vegetable foods are among the most commonly processed foods sold in markets and streets by out-of-school women. These same findings have been highlighted by similar studies of local products processed and marketed in West Africa [12-14]; however, they differ from those reported by Katinan et al. [15] and Koutou et al. [16] with men in majority, because traditionally, among breeders, milk belonged to woman, but with social changes of income managers occurring, some men are addressing this exploitation.

The type of livestock practiced, the domesticated dairy animal species, the type of milk used, the processing technology, the diversity of products obtained, and the fate of milk differ from one ethnic group to another [17] and from one region to another. Traditional livestock is reserved for the nomadic populations of Sahel (Fulani, Bella, Touareg and Haoussa) and only three high-performance dairy species producing large quantities of milk i.e., camel, goat and cow are exploited, while sheep is under exploited. However, nowadays, women transform milk powder imported from developed countries, contributing to degradation of the local milk sector; this finding was reported by Oudet [9] in Koudougou by Fulani women who practiced it.

In Burkina Faso, curd production technology plays an important role in the artisanal processing of fresh milk [18]. This technology is based on empirical knowledge and is transmitted from generation to generation within the family or the tribe. At Fulani level, girls learn with their mothers, close relatives, or mothers-in-law in the case that "milk work" is an important component of education: feeding of dairy female, milking, milk fermentation, churning, conditioning milk curd, maintenance of all dairy equipment, marketing of milk, curds, and butter. Thus, she will have full responsibility for leading her family microenterprise [19]. However, these traditional processes do not take care of maintaining the effective ferments to ensure products with good organoleptic qualities.

Drifting products (milk and meat) of these four species are traditionally eaten for sociocultural reasons. These diversities of sociocultural considerations have been evoked by previous studies concerning cultural and nutritional aspects, designating certain animals as Halal (Buffalo, deer, camel, horse, goat, sheep, cow) and other as Haram (donkey, cat, dog, lion, primates) by Benzertiha et al. [20]. Some unconventional milks (donkey, monkey) would be eaten for health reasons (mare) and mystical practices. Camel milk is commonly used to relieve convalescent patients, fatigue states, strengthen immune defenses and stimulate physical activity in overworked organisms [21]. These claims are based on purely empirical observations that sometimes seem to be more self-persuasive in some ethnic groups. Thus, the milk of camel and mare are precursors respectively of courage and speed at consumer level. In addition, the study revealed that curd is a highly valued food in Burkina Faso. It is consumed by all social classes, whatever is their education level and their economic situation and hence the importance of milk consumption is contributing to fighting malnutrition and food insecurity [22]. The use of unconventional veterinary inputs, clandestine purchase, non-compliance of waiting period, ignorance, or negligence of the rules of good hygiene practices, bad practices of trafficking, mismanagement of waste from mining and hospital sources, exposure of livestock feed on contamination and consumer perceptions are risky practices significantly affecting health animal 
status and sanitary quality of products of animal origin and rendering it unfit for human consumption. Previous studies in West Africa done by Savadogo et al. [23], Boko et al. [24], Coulibaly et al. [25], Kouamé-Sina et al. [6], Katinan et al. [15], Bonfoh et al. [26], Arohalassi et al. [5], in East Africa by Yilma et al. [27], Seifu [28], Seifu and Tassew [29], Ahmed et al. [30], in South Africa by Beukes et al. [31] and in North Africa by Aggad et al. [32] mentioned that these practices contributed to contamination of milk with pathogenic germs and toxic substances, rendering it unfit for human consumption and therefore a danger to public health.

Clinical signs cited by consumers (Figure 6B) are related to ingestion of milk contaminated with pathogens such as Staphylococcus aureus, Bacillus cereus, Salamonella, Shigella, E. coli, Pseudomonas and Enterococci faecalis from the udders, milking water, milker, environment, materials, manipulator, and insufficient treatment of milk. The presence of stray animals, birds, insects, and rodents would be a source of contamination of poorly stocked equipment and feed [6]. The antibiotic and pesticide residues would be at the origin of some clinical signs (digestive disorders, vomiting and diarrhea). Studies conducted by Arohalassi et al. [5] in Niger, Issa [33] in Mauritania, Bonfoh et al. [26] in Mali, Kouamé-Sina et al. [6] in Côte d'Ivoire and Samandoulougou et al. [34] in Burkina Faso reported different prevalence rates of antibiotic residues of $2.85 \%, 11 \%, 16.70 \%, 24.70 \%$ and $31 \%$ respectively in marketed animals.

Damages recorded in herds are strongly related to diseases contracted by animals. Among these diseases, salmonellosis, pulmonia, peripulmonia, diarrhea, mycoses, symptomatic anthrax, bloating, Brucellosis B are the most common and mastitis very frequent [35]. The non-treatment of sick animals, rejection of corpses of dead animals in the wild, and the negligence or ignorance of bovine vaccination campaigns cause the spread and persistence of diseases, hence the decimation of herds and making the milk and meat unfit for human consumption. Kouamé-Sina et al. [6] and, Razaa and Kim [36] reported that poor practices of actors, the presence of disease-carrying animals, poor management of household and industrial wastes, uncontrolled use of veterinary and agricultural inputs, engine pollution, and exposure of equipment and feed, similar to those observed during the investigation, are the source of the contamination of milk and dairy products (Figure 8 ). Improving the sanitary quality of origin of animal products, therefore, depends on good practice by the actors in the sector and the regulations adopted by the ministry to avoid cross-contamination $[6,36]$.

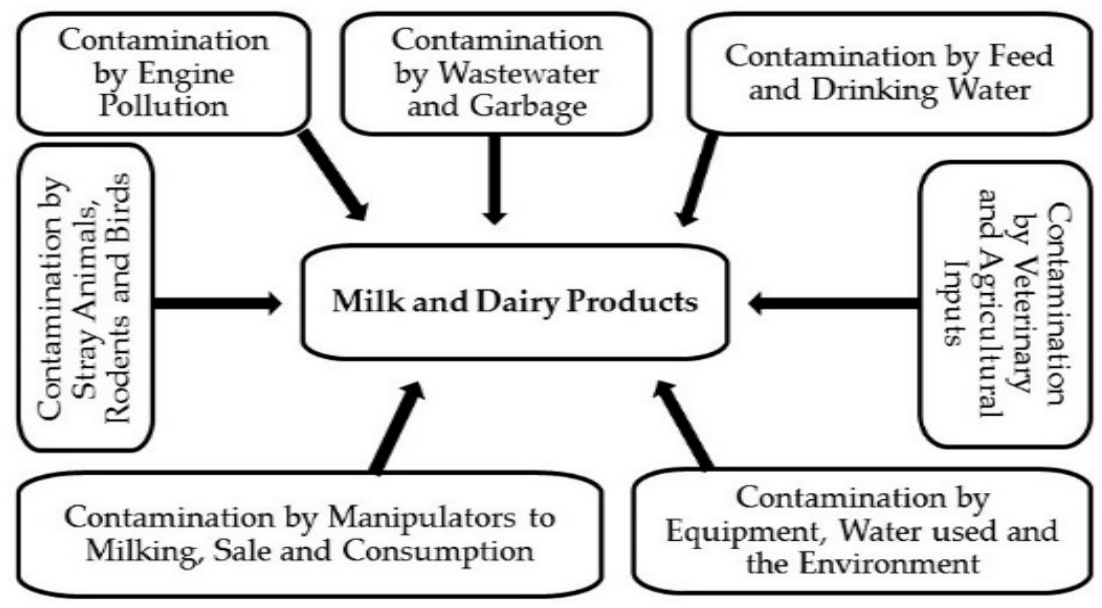

Figure 8. Source of the contamination of milk and dairy products.

In addition, the attention paid to the sanitary quality of products is becoming increasingly important in Africa, as in Burkina Faso, which is developing a guide to good hygiene practices in controlling dairy processing [37]. Food control authorities should implement a policy for quality practices, the popularization of these practices, as well as zootechnical supervision of actors in sector. 


\section{Materials and Methods}

\subsection{Literature Research}

Literature search was conducted to better understand the theoretical and practical aspects and to raise the interest of this study. Thus, the libraries of University Ouaga 1 Pr Joseph KI-ZERBO, Research Institute for Development (RID-Ouaga), Food and Agriculture Organization (FAO-Ouaga), Ministry of Animal and Halieutic Resources (MAHR) and Livestock Direction (LD) were consulted and additional information was obtained on the Internet using the following keywords: Livestock and Burkina Faso; Milk Sector and Burkina Faso; Milk and Dairy Products and Burkina Faso.

\subsection{Study Area and Period}

This study was conducted from December 2016 to February 2017 in five cities in Burkina Faso: Bobo

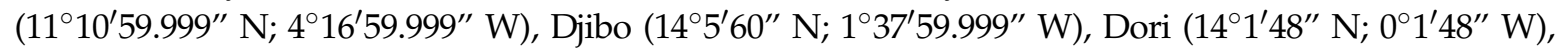

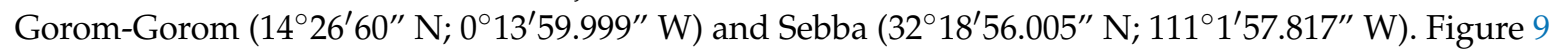
shows the study areas, the capital, and some provincial capitals. These five cities have been chosen because of their cosmopolitan character, the high density of livestock and the cultural diversity of people in social and food.

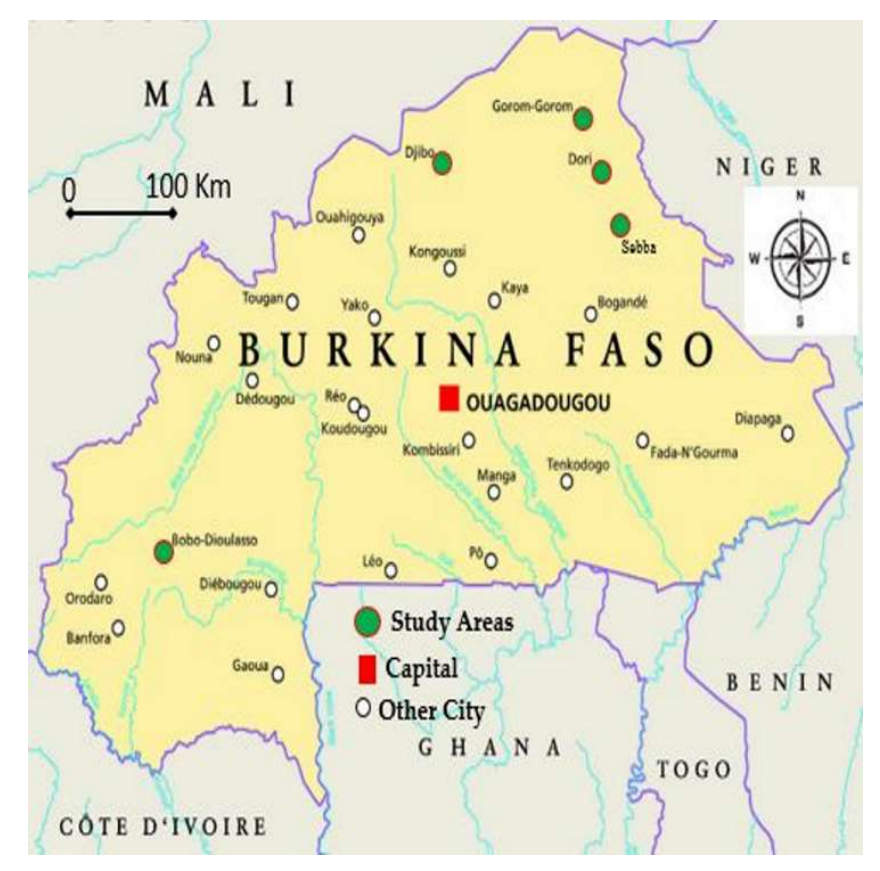

Figure 9. Location of study areas.

\subsection{Investigation}

A pre-investigation was used to test a pre-established questionnaire with dairy sector stakeholders (breeders, processors-sellers, and consumers) speaking different local dialects. This technique made it possible to adapt the questionnaire to sociological realities. Then, the questionnaire was sent individually to the people concerned. A total of 240 stakeholders of the local milk sector were investigated, including 80 breeders, 80 processor-sellers and 80 consumers (16 per city and category). The information mentioned on questionnaires serving as a maintenance guide is related to the sociodemographic status of the respondent, to technological aspects of processing fresh milk into curdled milk, consumer assessments, animal health status and sanitary risks involved. 


\subsection{Statistical Analysis}

Sphinx Plus ${ }^{2}-\mathrm{V} 5$ software was used for survey data processing and a $\mathrm{Chi}^{2}$ test was used for analysis variance (ANOVA) at a significance threshold of $p<0.05$.

\section{Conclusions}

The results of this study on different practices and risk analysis along the food chain in urban and rural areas challenge all actors working toward access of a healthy diet to educate and raise awareness about good hygiene practices, sanitation, use of veterinary or agricultural inputs and strict adherence to waiting times to protect the health of consumers. Thus, it is necessary to not only put special emphasis on good hygienic practices among producer-sellers and consumers, but also monitor the health status of animals. In the current context of globalization, the livestock sector is threatened by free-trading in food products, veterinary inputs, and its closely linked economy, which are at risk in coastal countries. Thus, the socio-economic incomes related to the activity of breeding are threatened, and it is essential to anticipate corrective measures to prepare Burkina Faso to facing and preserving its hegemony and animal inheritance.

Author Contributions: Investigation, Analysis and Writing-Original Draft Preparation are realized by H.C.; Data is organized by B.K.; Paper revised by A.S. and C.Z.; the validation of Results from Investigation and review of paper are supervised by Y.T. and A.S.

Funding: This research received no external funding.

Acknowledgments: We thank Aboubacar Ly, founder of the School of Wisdom in Dori for his collaboration and Gaston Sangaré for his help.

Conflicts of Interest: The authors declare no conflict of interest.

\section{References}

1. Consulat du Burkina Faso de NICE (CBFN). Les Bovins. 2016. Available online: http:/ /www.burkinafasocotedazur.org (accessed on 10 June 2017).

2. Plate-Forme d'Actions à la Sécurisation des Ménages Pastoraux (PASMEP). Lait Local: Plaidoyer Pour Sauver une Filière Menacée au Burkina Faso; PASMEP: Ouagadougou, Burkina Faso, 2016; p. 16.

3. Organization for Economic Co-operation and Development (OCDE)/Food and Agriculture Organization of the United Nations (FAO). Lait et Produits Laitiers: Perspectives Agricoles de l'OCDE et de la FAO 2016-2025; Éditions OCDE: Paris, France, 2016. [CrossRef]

4. Hamadou, S.; Sanon, Y. Diagnostic de la filière lait au Burkina Faso, Atelier de lancement du projet de recherche en collaboration. In Intégration Régionale, Accès aux Marchés et Diversification de l'Agriculture Dans la Zone UEMOA: Options Politiques Pour des Filières Laitières Compétitives et Durables; CESAG: Senegal, Dakar, 2005; p. 46.

5. Arohalassi, M.H.; Gounga, M.E.; Bada-Alambedji, R. Evaluation des pratiques d'utilisation des antibiotiques et de la qualité du lait dans la région de Maradi au Niger. Rev. Microbiol. Ind. Santé Environ. 2016, 10, 143-160.

6. Kouamé-Sina, S.M.; Bassa, A.; Dadié, A.; Makita, K.; Grace, D.; Dje, M.; Bonfoh, B. Analyse des risques microbiens du lait cru local à Abidjan (Côte d'Ivoire). Rev. Afr. Santé Prod. Anim. 2010, 8, 35-42.

7. Cadre d'Accélération des OMD (CAO). Application à L'OMD 1: Éliminer l'extrême pauvreté et la faim. In Assurer la Sécurité Alimentaire aux Petits Producteurs Pauvres (Hommes et Femmes) et Lutter Contre la Malnutritio; Rapport Final; CAO: Ouagadougou, Burkina Faso, 2010; p. 69.

8. Bonfoh, B.; Fane, A.; Traoré, N.A.; Coulibaly, Z.; Simbe, C.F.; Alfaroukh, O.I.; Nicolet, J.; Farah, Z.; Zinsstag, J. Qualité microbiologique du lait et des produits laitiers vendus en saison chaude dans le district de Bamako au Mali. Bioterre REVUE DES Sciences de la Vie et de la Terre 2002, 242-250. Available online: http://www.academia.edu/27495223/Qualit\%C3\%A9_microbiologique_du_lait_et_ des_produits_laitiers_vendus_en_saison_chaude_dans_le_district_de_Bamako_au_Mali (accessed on 13 July 2018).

9. Oudet, M. La Révolution Blanche Est Elle Possible au Burkina Faso, et Plus Largement en Afrique de l'Ouest? Éditée par MISEREOR: SEDELAN, Burkina Faso, 2005; p. 30. 
10. Akabanda, F.; Owusu-Kwarteng, J.; Glover, R.; Tano-Debrah, K. Microbiological characteristics of Ghanaian traditional fermented milk product. Nunu. Nat. Sci. 2010, 8, 178-187.

11. Herrero, M.; Havlik, P.; McIntire, J.; Palazzo, A.; Valin, H. L'avenir de L'élevage Africain: Réaliser le Potentiel de L'élevage Pour la Sécurité Alimentaire, la Réduction de la Pauvreté et la Protection de L'environnement en Afrique Sub-Saharienne; Bureau du représentant spéciale des Nations Unies pour la sécurité alimentaire et nutritionnelle et du Coordonnateur du système des Nations Unies contre la grippe (UNSIC): Geneva, Switzerland, 2014; p. 118.

12. Toko, R.C.; Adegbidi, A.; Lebailly, P. Valorisation des produits laitiers dans les ménages Peul du Nord-Est du Bénin. Int. J. Biol. Chem. Sci. 2015, 9, 2716-2726. [CrossRef]

13. Hongbete, F.; Kindossi, J.M.; Hounhouigan, J.D.; Nago, M.C. Production et qualité nutritionnelle des épis de maïs frais bouillis consommés au Bénin. Int. J. Biol. Chem. Sci. 2017, 11, 2378-2392. [CrossRef]

14. Ohin, B.M.; Adeoti, K.; Noumavo, P.A.; Kouhounde, S.H.; Garba, K.; Tovide, N.S.; Ogoua, S.; Baba-Moussa, L.; Toukourou, F.; Baba-Moussa, F. Technological Processes Itinerary and Socio-economic Impact Assessment of Borassus aethiopum Hypocotyles "Agonté" Produced in Centre of Benin Republic. Food Public Health 2018, 8, 35-41.

15. Katinan, C.R.; Aw, S.; Chatigre, K.O.; Bohoussou, K.M.; Assidjo, N.E. Assessment of chemical and microbiological quality of home-made fermented milk produced and consumed in Yamoussoukro town, Côte d'Ivoire. J. Appl. Biosci. 2012, 55, 4020-4027.

16. Koutou, M.; Sangaré, M.; Havard, M.; Toillier, A.; Sanogo, L.; Thombiano, T.; Vodouhe, D.S. Sources de revenus et besoins d'accompagnement des exploitations agricoles familiales en zone cotonnière ouest du Burkina Faso. Biotechnol. Agron. Soc. Environ. 2016, 20, 42-56.

17. Berhe, T.; Vogensen, F.K.; Ipsen, R.; Seifu, E.; Kurtu, M.Y.; Hansen, E.B. Traditional fermented dairy products of Ethiopia: A review. East Afr. J. Sci. 2017, 11, 73-80.

18. Savadogo, A.; Ouattara, C.A.; Savadogo, P.W.; Barro, N.; Ouattara, A.S.; Traoré, A.S. Identification of exopolysaccharides-producing lactic acid bacteria from Burkina Faso fermented milk samples. Afr. J. Biotechnol. 2004, 3, 189-194.

19. Konte, M. Le Lait et les Produits Laitiers. Développement de Systèmes de Productions Intensives en Afrique de L'ouest. Master's Thesis, Université de Nouakchott, Nouakchott, Mauritanie, 1999; p. 25.

20. Benzertiha, A.; Kierończyk, B.; Rawski, M.; Jozefiak, A.; Mazurkiewicz, J.; Jozefiak, D.; Messikh, M.S.; Świątkiewicz, S. Cultural and practical aspects of halal slaughtering in food production. Med. Weter. Vet. Med. Sci. Pract. 2018, 74, 371-376. [CrossRef]

21. Konuspayeva, G.; Loiseau, G.; Faye, B. La plus-value «santé» du lait de chamelle cru et fermenté: L'expérience du Kazakhstan. In Onzièmes Rencontres Autour des Recherches sur les Ruminants; Institut de l'élevage: Paris, France, 2004; Volume 11, pp. 47-50.

22. Sessou, P.; Yegrave, B.; Agniwo, B.; Alitonou, G.; Azokpota, P.; Youssao, I.; Sohounhloue, D. Biological control of spoilage and pathogens moulds in culture medium and Beninese traditional cheese wagashi by Syzygium aromaticum essential oil. Afr. J. Microbiol. Res. 2013, 7, 2454-2463.

23. Savadogo, A.; Ouattara, C.A.T.; Savadogo, P.W.; Ouattara, A.S.; Barro, N.; Traoré, A.S. Microorganisms involved in Fulani traditional fermented milk in Burkina Faso. Pak. J. Nutr. 2004, 3, 134-139.

24. Boko, C.; Adje, Y.; Atindogbe, G.; Hounmanou, M.G.Y.; Dossa, F.; Sessou, P.; Farougou, S. Evaluation of the production technologies and the microbial and physicochemical qualities of curdled milk produced in Benin. J. Appl. Biosci. 2016, 104, 10019-10033. [CrossRef]

25. Coulibaly, K.J.; Kouame-Elogne, C.; Yeo, A.; Koffi, C.; Dosso, M. Qualité microbiologique des produits laitiers industriels vendus à Abidjan de 2009 à 2012. Rev. Biol. Afr. 2015, 14, 44-52.

26. Bonfoh, B.; Wasem, A.; Traoré, A.N.; Fané, A.; Spillmann, H.; Simbé, C.F.; Alfaroukh, I.O.; Nicolet, J.; Farah, Z.; Zinsstag, J. Microbiological quality of cows' milk taken at different intervals from the udder to the selling point in Bamako (Mali). Food Control 2003, 14, 495-500. [CrossRef]

27. Yilma, Z.; Loiseau, G.; Faye, B. Manufacturing efficiencies and microbial properties of butter and Ayib-Ethiopian cottage cheese. Livest. Res. Rural Dev. 2007, 19, 1-88. Available online: http://www. lrrd.org/lrrd19/7/yilm19088.htm (accessed on 24 June 2018).

28. Seifu, E. Chemical composition and microbiological quality of Metata Ayib: A traditional Ethiopian fermented cottage cheese. Int. Food. Res. J. 2013, 20, 93-97. 
29. Seifu, E.; Tassew, A. Small-scale milk processing, utilization and marketing of traditional dairy products in Bahir Dar Zuria and Mecha districts, northwestern Ethiopia. J. Food Technol. Res. 2014, 1, 122-132. [CrossRef]

30. Ahmed, A.I.; Mohammed, A.A.; Faye, B.; Blanchard, L.; Bakheit, S.A. Assessment of quality of camel milk and gariss, North Kordofan State, Sudan. Res. J. Anim. Vet. Sci. 2010, 5, 18-22.

31. Beukes, E.M.; Bester, B.H.; Mostert, J.F. The microbiology of South African traditional fermented milks. Inter. J. Food Microbiol. 2001, 63, 189-197. [CrossRef]

32. Aggad, H.; Mahouz, F.; Ammar, Y.A.; Kihal, M. Evaluation de la qualité hygiénique du lait dans l'ouest algérien. Rev. Méd. Vét. 2009, 160, 590-595.

33. Issa, G.A.R. Evaluation des Pratiques D'utilisation des Médicaments Vétérinaires et Détermination de la Prévalence des Résidus d'Antibiotiques dans la Viande et le Lait Dans le Gorgol en Mauritanie. Master's Thesis, Université Cheick Anta DIOP, Dhaka, Senegal, 2012; p. 31.

34. Samandoulougou, S.; Ilboudo, A.J.; Bagre, S.T.; Tapsoba, W.F.; Savadogo, A.; Scippo, M.L.; Traoré, S.A. Screening of antibiotics residues in beef consumed in Ouagadougou, Burkina Faso. Afr. J. Food Sci. 2015, 9, 67-371.

35. Vikou, R.; Doko, S.Y.; Aplogan, L.G.; Ahanhanzo, C.; Baba-Moussa, L.; Gbangboche, A.B. Effect of somatic cells on the yield, clotting time and organoleptic quality of Wagashi. JAPS 2018, 36, 5785-5792.

36. Raza, N.; Kim, K.H. Quantification techniques for important environmental contaminants in milk and dairy products. TrAC Trends Anal. Chem. 2017, 98,79-94. [CrossRef]

37. Comité de Suivi Pour L'élaboration du Guide de Bonnes Pratiques D’hygiène (CSEGBPH). Maîtrise de la qualité dans la transformation laitière au Burkina Faso. In Guide de Bonnes Pratiques D'hygiène; Ministère des Ressources Animales et Haliautiques: Ouagadougou, Burkina Faso, 2005; p. 94.

(C) 2018 by the authors. Licensee MDPI, Basel, Switzerland. This article is an open access article distributed under the terms and conditions of the Creative Commons Attribution (CC BY) license (http:/ / creativecommons.org/licenses/by/4.0/). 